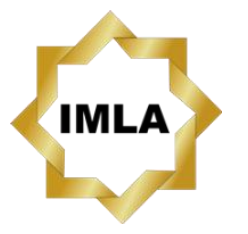

Available online:

http://journal.imla.or.id/index.php/arabi

Arabi : Journal of Arabic Studies, 5 (1), 2020, 1-10

DOI: http://dx.doi.org/10.24865/ajas.v5i1.246

\title{
SKETCHING THE SEMANTIC CHANGE OF JAHANAM AND HIJRAH: A CORPUS BASED APPROACH TO MANUSCRIPTS OF ARABIC-INDONESIAN LEXICON
}

\author{
Dewi Puspita', Kamal Yusuf ${ }^{2}$ \\ ${ }^{1}$ Universitas Indonesia, Depok, Indonesia \\ ${ }^{2}$ Universitas Islam Negeri Sunan Ampel Surabaya, Indonesia \\ E-mail : dewi_puspita18@yahoo.com
}

\begin{abstract}
There are a significant number of lexical borrowings from Arabic language to Indonesian language. Among of them are the words jahanam and hijrah. These words are diachronically can be traced and found in literatures and religious texts. This paper seeks to scrutinize the semantic change of jahanam and hijrah. This paper analyses jahanam and hijrah as they are used in both old manuscripts and modern texts. To see their semantic change behaviour, collocation and concordance of their contexts were analysed. The manuscripts employed as the source of research data were taken from the Malay Concordance Project (MCP) which comprises of 165 classical Malay literatures containing some Islamic texts, Corpora Collection Leipzig University, and WebCorp Live Birmingham City University. Using the corpus linguistics method, this research manages to demonstrate how words change semantically through time. The results of this study can be used as material for the preparation of the IndonesianArabic etymology dictionary.
\end{abstract}

Keywords: manuscript, diachronic, corpus linguistics, semantic change

\begin{abstract}
Abstrak
Cukup banyak leksikon bahasa Arab yang diserap oleh bahasa Indonesia, antara lain, seperti kata jahanam dan hijrah. Secara diakronis, kata tersebut dapat ditelusuri di dalam teks kesusasteraan dan keagamaan. Makalah ini berusaha menelusuri perubahan makna pada kata jahanam dan hijrah. Tulisan ini bertujuan menganalisis kata jahanam dan hijrah yang digunakan dan terdapat pada manuskrip-manuskrip kuno serta teksteks modern dengan melihat perilaku semantisnya, kolokasi, serta konkordansinya dalam konteks. Untuk itu, sumber data yang digunakan dalam penelitian ini berasal dari Malay Concordance Project (MCP), terdiri atas 165 karya sastra Melayu klasik dan teks-teks keislaman. Selain itu, data juga bersumber dari Corpora Collection Leipzig University, dan WebCorp Live Birmingham City University. Dengan menggunakan metode linguistik korpus, temuan penelitian ini menunjukkan bagaimana kata-kata mengalami perubahan semantik secara diakronis. Hasil penelitian ini dapat digunakan sebagai materi untuk penyiapan kamus etimologi bahasa Indonesia-Arab.
\end{abstract}

Kata Kunci: manuskrip, diakronis, linguistik korpus, perubahan makna 


\section{Arabi : Journal of Arabic Studies}

\section{Introduction}

The contents of manuscripts scattered across the Indonesian certainly bring a lot of foreign vocabulary to the archipelago. Many foreign vocabularies are then absorbed into Malay (Liaw Yock Fang, 1991; Riddell, 2012). There are complete forms of absorption (the exact spelling and pronunciation) and some are adjusted both spelling and pronunciation. The arrival of Islam to the archipelago has brought a great influence not only in religion and culture, but also in language (Pusat Pembinaan dan Pengembangan Bahasa, 1996; Berg, 2007; Jones et. al., 2007; van Dam, 2010). This can be seen from the many Arabic words that enrich Malay and Indonesian vocabulary through absorption and borrowing (Julul, et.al., 2019). In 1996, the book of Senarai Kata Serapan dalam Bahasa Indonesia (List of loan words in Indonesian) recorded 1,495 loanwords from Arabic. That number might have been increased by now.

Many of the Arabic loanwords' meanings have now been deviated far from the original meaning. The change in meaning is natural because languages, including its vocabulary, always develop and change. Contact with outside culture causes some vocabularies to change some of its sound, form, and or meaning from its original especially when language users have no prior knowledge on the etymology or the history of the word.

People currently study one manuscript at one time carefully to get the core and lessons from it due to an uncertain amount of time needed to study many manuscripts. An effective and efficient method for studying large numbers of manuscripts is the corpus linguistic method. Corpus linguistics can simplify and make the work for months or even years into just a couple of minutes. Corpus linguistics is a research method that utilizes corpus data that is a collection of pieces of language text in electronic form, selected according to external criteria to represent, as far as possible, a language or language variety as a source of data for linguistic research (Sinclair, 2004). O'Donnell (2008) further explains that corpus data contains authentic language data designed and collected according to sampling procedures in an electronic or machine-readable form. The data is a representative of language and used for linguistic investigation. In corpus linguistics, what is meant by digitalization is not just the transfer of media from print to digital media, but it is more about digitalization that makes the manuscripts readable by the corpus tools. To be used in the corpus, manuscripts must be converted into a plain file.

Researchers interested in studying manuscripts through corpus are now facilitated by the existence of the Malay Concordance Project (MCP). MCP is a corpus of classical Malay texts developed by Ian Proudfoot (1991), comprising 165 texts and 5.8 million words, including 140,000 verses, dating from the 14th to the 20th century. Those texts are collected from some reputable philologists (Gallop, 2013). The corpus provides useful information about contexts in which words are used, where particular terms or names occur in texts, and patterns of morphology and syntax.

There have been many studies conducted using MCP, including linguistics research. Among them are studies by Siaw-Fong Chung (2011) on a corpus based study on the uses of the affix "ter" in Malay, Wade and Li's (2012) study of Anthony Reid and the study of the Southeast Asian Past, and also Maziar (2012) who study about Malay kingship in Kedah, its religion, trade, and society. MCP has made it much easier to research about Malay and Indonesian. There are some more corpora on Malay and Indonesian language, but the texts they contained is not of manuscripts. The oldest texts would be from the $20^{\text {th }}$ century and some of them originated in digital form. For some research, that does not cover all the need. Another way to do this is by comparing two or more different corpora from different era.

Corpus like MCP can be set diachronically so that user can see from the concordance or word collocates whether a word has similar or different meaning from time to time. We can also compare corpus of old data with another corpus from a more current data. From the time shown in the corpus we can also see when the changes occurred.

One example of the utilization of digitized Islamic text for linguistics research has been carried out by Nor Hashimah et al (2012) in his research on the change of meaning of the word

Vol. 5 No. $1 \mid 2-10$

Copyright @ 2020 | ARABI | p-ISSN 2548-6616 | e-ISSN 2548-6624 
alim in Malaysian. Although the focus of the research is on cognitive semantic analysis, the words analysed and the data sources used are examples of how digital Islamic texts are utilized in transdisciplinary linguistic research. Nor Hashimah et al analysed how the meaning of Arabicorigin word alim has change through time by looking at the concordance of alim in UKM-DBP (Malaysian Language and Library Council) corpus. UKM-DBP corpus is a 5 million words data taken from UKM-DBP data bank which comprises of newspaper, magazines and books. Unfortunately, as mentioned previously, the corpus contains many Islamic texts but none of them are of old manuscripts. From the corpus, she found that there are four new meaning of the word alim in addition to its original meaning. From that finding they continue the analysis to cognitive semantic.

To the best of our knowledge, there is no previous research that has investigated the semantic change of Indonesian lexicon from Arabic origin utilising corpus method. Using corpora in analysing the semantic change can be advantageous in threefold: (1) it enables us to track different language used of a word across the time, (2) it gives us an authentic evidence of changes in a language through time, and (3) it helps us to identify new meanings of a word. Therefore, this paper was aimed to investigate the Indonesian lexicon of Arabic origin. In more specific, the words jahanam and hijrah will be tracked. These two words are considered frequently used recently in media. As a result, this study aims at describing how these words have changed semantically from their origin word in Arabic as well as at tracing them diachronically from time to time. Additionally, this research offers to demonstrate how to use of Islamic manuscripts for study in the field of applied linguistics by exploiting the available online corpora.

\section{Method}

To analyse the semantic change of the current researched words, we used corpus- based approach. There were three corpora used in this research, namely MCP, Indonesian corpus from Corpora Collection Leipzig University (Leipzig Corpora), and WebCorp Live. To mention some of Islamic manuscripts stored in MCP used as the source of data in this study. Table 1 presents their list.

Table 1. Islamic manuscripts in MCP

\begin{tabular}{clc}
\hline Nr. & Title & Year \\
\hline 1 & Qasidah al-Burdah & MS <1604 \\
2 & Aqa''idal-Nasafi & $\sim 1590$ (MS 1590) \\
3 & Bustan al-Salatin & $\sim 1640$ \\
4 & Hujjat al-Siddiq & $1641-1644$ (MS 1772) \\
5 & Surat al-Anbiya' & $\sim 1750$ (MS 1877) \\
6 & Risalah fi 'l-Tawhid & 1760 s (MS 1823) \\
7 & Syair Mekah Madinah & $\sim 1835$ \\
8 & Hikayat Iblis & 1846 \\
9 & Pelayaran Abdullah ke Mekah & 1854 \\
10 & Mukhtashar Tawarikh al-Wusta & 1854 \\
11 & Tuhfat al-Nafis & $1866(\mathrm{MS} 1890)$ \\
12 & Hadiqat al-Azharwa'l-Riyahin & $1889(\mathrm{MS} \mathrm{1889+)})$ \\
13 & Muhimmat al-Nafa'is & 1892 \\
14 & al-Imam & $1906-1908$ \\
15 & Itqānal-Mulk bi Ta'dilal-Sulük & 1911 \\
\hline
\end{tabular}

Leipzig Corpora is a collection of on-line corpus developed by the Institute of Computer Science, University of Leipzig, Germany which contains 358 corpuses from 252 languages in the world. Corpus data was taken from internet pages. All corpora were processed in the same way so that all contain well-formed sentences in each language. The sentences were then sorted randomly so that the use of web data for the corpus did not violate copyright because it was not possible to reconstruct the entire original text. The Indonesian corpus in Leipzig Corpora consists of $74,329,815$ sentences, 7,964,109 types, and 1,206,281,985 tokens. Data come from the year range 


\section{Arabi : Journal of Arabic Studies}

of the 2010s to 2014s. The year of appearance can be seen in the corpus so that it can be sorted chronologically.

WebCorp Live is an online corpus project developed by Birmingham City University. Similar to Leipzig Corpora, WebCorp Live also retrieves data from web pages on the Internet. While Leipzig Corpora uses its own search engine, WebCorp uses the Bing search engine for the Indonesian language. In addition, because WebCorp is a device that is directly connected to the internet at the time of the search, the amount of data cannot be known, really depends on the availability of data in the network. The range of the year also depends on the availability of data, the longest is from the early 2000s and the most recent is from the current year.

This research employed collocation and concordance features as the basis for analysing jahanam and hijrah in their contexts. Collocation was used to describe the broader context of these words. Concordance provide the overall uses of the lexical items whereas, collocation determines the textual behaviour of the node word. Through concordance the lexical items are explored with specific reference to their dynamic nature of meaning, while collocation specifies the cooccurrence of various lexical items with the node words (Zahra \& Abbas, 2018).

\section{Result and Discussion}

\section{Semantics change of Jahanam}

The first word to be analysed in this research was the word "jahannam" or "jahanam" in Indonesian context. If we look at its original usage from the Quran or Islamic texts, jahannam is a name of a hell. In the MCP data it was found that there are 84 concordance lines containing the word jahanam (with one letter $\mathrm{m}$ ) and Jahannam (with two letter $\mathrm{m}$ ). Those concordance lines are derived from several texts. Most of the word jahan(n)am in the data from the 14th century to the 19th century were in collocation with neraka (34 times). Both words form the word neraka jahanam as can be seen in the following concordance lines.

Table 2. The concordance of "jahanam" and its variation in MCP (from the 14th to 19th century)

\begin{tabular}{|c|c|}
\hline \multicolumn{2}{|l|}{ TM Kahf 102} \\
\hline & \\
\hline \multicolumn{2}{|r|}{ TM Mrym 68maka Kami hadirkan mereka itu kelilingnya neraka jahanam dengan berlutut $〉$ atas lutut mereka itu. 〈Kemu } \\
\hline \multicolumn{2}{|c|}{ TM Mrym 70..... mereka yang terlebih patut akan masuk» neraka jahanam dan tunu. «Dan tiada〉 seorang jua pun «daripada } \\
\hline \multicolumn{2}{|r|}{ TM Mrym 71. jua pun «daripada kamu melainkan〉 masuk neraka jahanam ya ni «melalui dia. Dan adalah` melalui dia itu } \\
\hline \multicolumn{2}{|r|}{ TM Mrym 75〈dan ada kalanya kiamat〉 yang mengandung neraka jahanam, 〈maka lagi akan diketahui oleh mereka itu a } \\
\hline \multicolumn{2}{|r|}{ TM Mrym 86kafir〉 dengan sebab kufr mereka itu «kepada neraka jahanam padahal mereka itu berjalan〉 lagi dahaga. 〈Tia } \\
\hline 11 & a \\
\hline \multicolumn{2}{|r|}{ TM Taha 134 ..... pada hari kiamat 〈dan dihinakan〉 dalam neraka jahanam?" 〈Kata olehmu〉 bagi mereka itu, ya Muhammad } \\
\hline \multicolumn{2}{|r|}{ Anb 247:6 ...... oleh Nabi Allah Ibrahim peri akan seksa neraka jahanam daripada segala bukitnya dan pihaknya itu daripa } \\
\hline Anb 351:35 & ... terminumlah aku takut pada pagi jemah neraka jahanam itu." Maka oleh Puteri Siti Zulaikha akan Nabi \\
\hline Anb 685:7 & lepaskan kiranya bukit ini daripada seksa neraka jahanam itu." Maka didengar Nabi Allah `Isa: "TelahKu \\
\hline & \\
\hline
\end{tabular}

In other data, the word jahan(n)am is paired with words that relate to sin, the torment of hell, and religious words. Only in the $20^{\text {th }}$ century, the word jahanam is being put in other context than religion as can be seen in the following concordances.

Table 3. The concordance of "jahanam" and its variation in MCP

(from the 20th century)

Das 36:1d tidak dapat selamat, sebab kerja jahat amat, bikin jahanam sama umat*| Orang jahat tipu daya, macam mana pa S 9May31:1 bodoh, peraturan yang mana telah menjadikan jahanam nama dan kehidupan sesuatu bangsa di dalam dunia ini

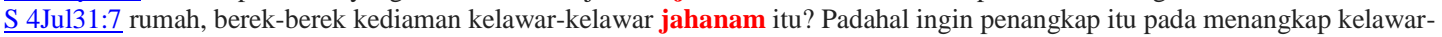

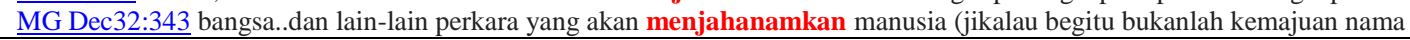

In those lines jahanam carried the meaning of trouble, evil, and all bad things. 
In the other corpus, Leipzig Corpora, there are two different results from the search for the word jahanam. The first is the search result of the word jahanam in Islamic texts; the second is the search result for the word jahanam in the general text. The first search of results show the collocation as in Figure 1.

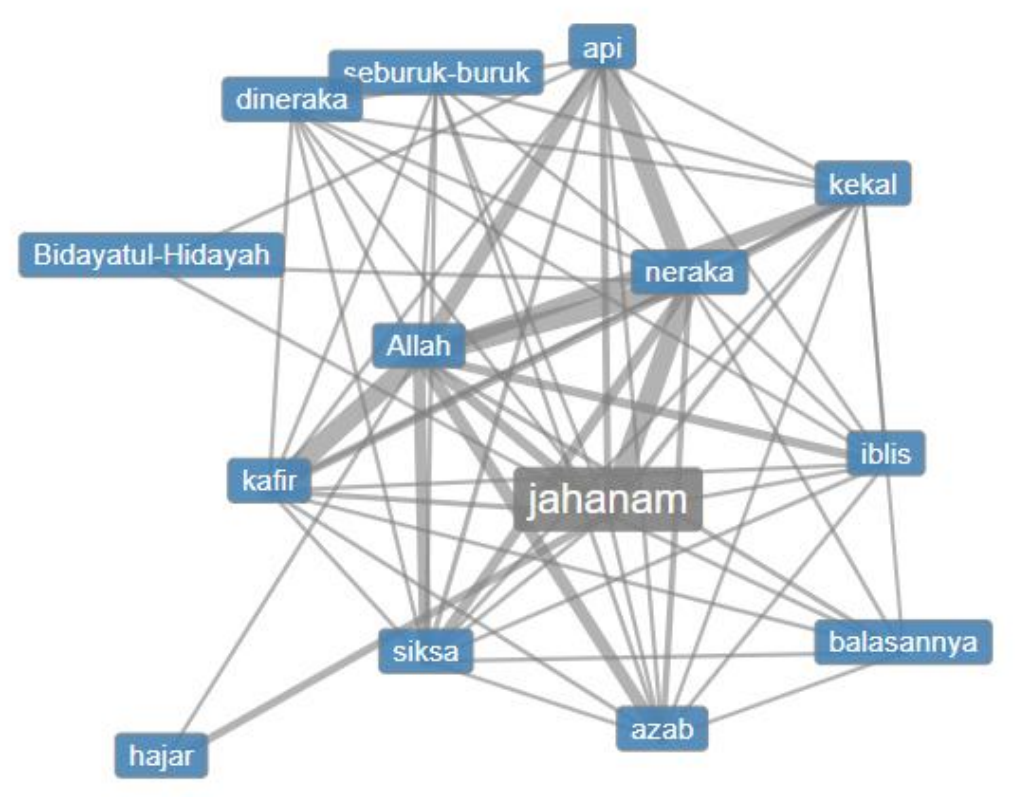

Figure 1. Collocates of "Jahanam" from digitised Islamic texts in Corpora Collection Leipzig University

Digitised Islamic texts in Leipzig Corpora associate the word jahanam strongly with hell, devil, eternal, fire, punishment, torment, and Allah, as shown in Figure 1. However, a more recent data corpus shows a quite different usage of the word in context as depicted in Table 4 and 5 as follow.

Table 3. Data from Corpora Collection Leipzig University (retrieved 03/08/2019)

- Cukup sekali saja kita membayar uang tebusan kepada para perompak jahanam di Somalia. (www.suarapembaruan.com, crawledon 26/04/2012)

- Lelaki jahanam itu harus terima pembalasan dari aku suatu hari nanti. (qasehlyaaqila.blogspot.com, crawledon 08/05/2012)

- Dan gua baru nyadar map ini adalah map jahanam dimana akses untuk ke base musuh itu sedikit sulit. (www.kaorinusantara.web.id, crawledon 09/02/2014)

- Di bawah sinar purnama kembang memberanikan diri untuk keluar dari sarang jahanam itu. (digilib.utm.ac.id, crawledon 02/02/2014)

- Kita tidak kalah melawan para perompak jahanam itu. (www.suarapembaruan.com, crawledon 26/04/2012)

- Anak-anak itu bertahan hidup dengan makan dari sisa-sisa para mandor jahanam. (www.kayongutarakab.go.id, crawledon 31/01/2014)

- Ia menawarkan obat kuat Arab yang sangat terkenal, yaitu hajar jahanam. (akusaeni.blogspot.com, crawledon 08/05/2012)

- Saya ambil beberapa helai daun jahanam yang tengah di jemur oleh anak buah Papa untuk saya linting. (jatim.bkkbn.go.id, crawledon 31/01/2014)

- Namun aku sangat takut akan jarum suntik jahanam itu. (kisahbebe.blogspot.com, crawledon 08/05/2012)

- Ramuan yang paling banyak dicari pria dewasa adalah ramuan hajar jahanam yang berfungsi sebagai obat kuat. (www.hajarjahanam.web.id, crawledon 30/01/2014) 


\section{Arabi : Journal of Arabic Studies}

Table 4. Data taken from WebCorp Live, Birmingham City University, (retrieved 03/08/2019)

1) https://food.grab.com/id/id/restaurant/warunk-sambel-bh-bang-harim-tegalrejo-delivery/IDGFSTI00000

Text, Wordlist, text/html, UTF8 (Content-type), 2019-01-01 (Copyrightfooter)

asi Grab Ayam Ayam Goreng Ayam Bakar Ayam Jahanam Ayam Kampung Kremes Ayam Goreng Kam

Telor Asin Menu Spesial Lele Guyur Pedas Bebek Jahanam GurameTelor Asin GurameGorelBh Lele

Paket C - 3 Orang Gurame Goreng Bh, Bebek Jahanam , Lele Guyur Pedas, Cap Jay Goreng, Samb

2) https://www.suara.com/lifestyle/2018/01/09/160453/cicipi-gurihnya-ayam-geprek-mozzarella-yang-lagi-

Text, Wordlist, text/html, UTF8 (Content-type), 2019-01-01 (Copyrightfooter)

Ayam GeprekMozzarella di Kedai Ayam Geprek Jahanam (AGJ) Bang Samson di BSD, Tangerang Sela.. dengan sambal pedas yang diberi nama "sambal jahanam ", serta nasi gurih hangat, perpaduan ini te..

Selain rasa dan inovasi menunya, sambal jahanam yang dimiliki AGJ Bang Samson, berhasil

3) https://www.nibble.id/blog/ayam-geprek-di-jakarta-yang-pedasnya-nampol-banget/

Text, Wordlist, text/html, UTF8 (Content-type), 2019-01-01 (Copyrightfooter)

bisa didapat dengan harga Rp.25.000 saja ini jahanam banget enaknya! Lokasi: Geprek Jahanam saja ini jahanam banget enaknya! Lokasi: Geprek Jahanam Bang Samson Taman Jajan Fat Guy, Ruko

4) https://www.pegipegi.com/travel/8-kedai-ayam-geprek-di-jakarta-yang-pedasnya-mantap/ Text, Wordlist, text/html, UTF8 (Content-type), 2017-05-05 (Bodynear 'LastModified')

foto dari: https://m.qraved.co Kenapa ada kata ' jahanam ' di kedai ini? Soalnya GeprekJahananBa memang ingin menawarkan cita rasa pedas yang jahanam ! Enaknya sih, ayam geprek di sana disaji

tentukan sendiri sesuai selera. Lokasi Geprek Jahanam Bang Samson agak sedikit jauh dari Jakar

The word jahanam in recent corpora is no longer used solely in religious contexts; its use is now widespread. The word is used in any context that associates with evil or crime. Some people even use the word to name and describe food. The meaning of jahanam has expand to 'evil', 'strong as hell', and 'hot as hell' (see Table 5).

For Indonesian who understands Arabic, this sort of thing might not a new or an interesting thing, but for Muslims in other country and culture, this might be shocking. Some culture might never associate good, tasty food with hell. For linguists, it is the expanded meaning and what is beyond the expanded meaning that draws their attention. This is a researchable phenomenon.

\section{Sketching the meaning of Hijrah}

Another word case widely used among Indonesian young millennials is hijrah. The word hijrah etymologically means moving from one place to another. In Islam, hijrah means the departure of Prophet Muhammad from Mecca to Medina with the aim of saving himself and spreading the Islamic teachings (as shown in figure 3). Hijrah is also related to the dates of Islam which began when the Prophet Muhammad moved to Medina.

Data from the 14th to 19th centuries as found in the MCP shows that hijrah or its variation hijrat occurs in many texts and refers to the year of Islamic calendar. The word hijrah or hijrat collocates with number of years, and such words as nabi, baginda, Muharam, and 12 Rabiulawal as demonstrated in Table 6 below.

Table 6. The concordance of "hijrah" and its variation in MCP (from the 14th to 19th century)

\begin{tabular}{l}
\hline BS.L 2/13:27 .. tahun. Kemudian dari itu alah Nias pada tatkala Hijrah seribu tiga puluh empat tahun. Kemudian dari itu ma \\
BS.L 2/13:48 . hikayat, adalah baginda berangkat ke Pasai pada Hijrah seribu empat puluh dulapan tahun. Sekali peristiwa \\
BS.L 2/13:55 pada hari Isnin, enam hari bulan Zulkaedah pada Hijrah seribu lima puluh tahun. Dan ialah yang bergelar \\
BS.L 2/13:73 ... pada hari Arba`a, tiga hari bulan Syaaban, pada Hijrah seribu dulapan puluh enam tahun. Dan ialah bergelar \\
S 18May31:4 engah daripada setengah berkenaan dengan tahun Hijrah. Adapun hasil bagi 12 bulan yang lepas di dalam \\
S 18May31:4 .. perjalanan ugama Islam. Maka pada awal tahun Hijrah 1347, Duli Yang Maha Mulia al-Sultan bersetuju \\
TZA 1.2a. lagipun terang, mulai mengarang bulan Muharam. | Hijrat Nabi Penghulu kita ..., seribu tiga ratus bilangan \\
TZA 1.348c .. masa awal tahuni, tiga puluh tujuh hai ikhwani, hijrat nabi akhira zamani, tiada bertukar saat begini. | Data \\
TZA 1.366d . malam Isnin masa waktu, tiga puluh tujuh tahun Hijrah tu. | Baginda sedang bersuka-suka, dengan isteri p \\
TZA 1.906d ... bercahaya, daripada Syaaban bulan yang mulia, hijrat Nabi Rasul bahagia. | Seribu tiga ratus pada hitung \\
TZA 1.950c .... dua Ramadan bilangan hari, seribu tiga ratus Hijrat Mukhtari, tiga puluh lapan konon khabari. | Bahawa \\
TZA 1.1137a sultan yang mutu, gemuruhlah bunyi ketika itu. | Hijrah Nabi akhiru'l-zaman, seribu tiga ratus bilangan t \\
\hline
\end{tabular}

Vol. 5 No. $1 \mid 6-10$

Copyright @ 2020 | ARABI | p-ISSN 2548-6616 | e-ISSN 2548-6624 
\begin{tabular}{l}
\hline TZA 2.595c ri bulan Zulkaedah yang mulia, empat puluh enam hijrat anbia, pukul sepuluh pagi bertolak dia. | Pukul lima \\
TZA 2.1182a ... lama zamani, sampailah hari bertabal sultani. | Hijrah Nabi Allah Rahmah ..., seribu tiga ratus masa terje \\
TZA 2.1252a ........ saat ketika, memulai kerija sultan paduka. | Hijrat Nabi akhiru'l-zamani, seribu tiga ratus hai ikhwani, \\
TZA 2.1323a peri, berlengkap kealatan di dalam negeri. | Pada hijrat Nabiu'l-mukhtara, seribu tiga ratus sudah dikira, li \\
S 1Aug36:2 seperti hari raya puasa, hari raya haji, pada tahun hijrah 12 Rabiulawal hari lahir Nabi kita Muhammad dan s \\
\hline
\end{tabular}

However, at the present time, the meaning of hijrah has been expanded. This word has been used differently as hijrah is now associated with repentance or change. However, the changes tend in the way of dress or fashion styles, such as the use of gamis, braids, wearing beard, etc. All these things are regarded as the embodiment of devotion and repentance for hijrah. This word is also now expanding its use in many fields, not only related to religious term, but also used in sport. The concordance lines in Table 7 exemplifies the co-occurrences of hijrah in the field of sport, which demonstrate the collocation of the word with Real Madrid, club, transfer, liga, United, Milan, etc.

Table 7. Data from Corpora Collection Leipzig University (retrieved 07/10/2019)

- $\quad$ Forlan menyebut tak seorang pun memaksanya hijrah. (us.bola.viva.co.id, crawled on 12/02/2014)

- Menurutnya, Gilardino tak akan mengikuti jejak Prandelli jika pelatihnya itu benar-benar akan hijrah ke Juventus. (maps.google.co.id, crawled on 09/02/2014)

- Cedera dan hukuman kerap kali menyelimuti Super Mario setelah dua tahun hijrah ke Etihad Stadium. (www.bolanews.com, crawled on 05/01/2013)

- The Red Devils sedang diterpa rumor rencana hijrah Wayne Rooney. (forum.hon.garena.co.id, crawled on 12/02/2014)

- Playmaker Rusia ini seringkali diberitakan akan hijrah ke Inggris atau Spanyol. (us.m.bola.viva.co.id, crawled on 11/02/2014)

- Namun Richards nampaknya akan menepis tawaran hijrah ke Santiago Bernabeu itu. (us.m.bola.viva. co.id, crawled on 10/02/2014)

- $\quad$ Roberto Soldado juga memiliki kemungkinan hijrah dari Bernabeu dan sudah ditawar oleh klub Portugal, Benfica. (www.suarakarya-online.com, crawled on 25/04/2012)

- Juga Rudi Widodo yang baru saja hijrah dari Persibo Bojonegoro. (www.suarakarya-online.com, crawled on 25/04/2012)

- Ia hijrah ke AS Monaco karena ketatnya persaingan di AC Milan. (Christian Vieri, crawled on 21/10/2007)

- $\quad$ Kini ia harus hijrah ke Liga Inggris setelah The Reds memboyongnya. (kaorinusantara.web.id, crawled on 11/02/2014)

- Awalnya, Altintop mengungkapkan bahwa ia akan hijrah ke Liga Premier atau tetap bermain di Bundesliga. (www.bolanews.com, crawled on 25/04/2012)

- Jika kondisi seperti ini dibiarkan terjadi, maka bukan mustahil Bosingwa akan hijrah dari Stamford Bridge. (us.m.bola.viva.co.id, crawled on 12/02/2014)

- Pasukan San Paolo juga baru saja kehadiran Jose Callejon yang hijrah dari Real Madrid. (www.ftmd.itb.ac.id, crawled on 08/02/2014)

- Winger Bayern Munich itu akan hijrah ke Old Trafford jika Ronaldo pergi. (us.m.bola.viva.co.id, crawled on 08/02/2014)

- Apalagi, The Reds tidak lagi dibesut oleh manajer Rafael Benitez yang hijrah ke Italia. (us.m.bola.viva. co.id, crawled on 09/02/2014)

- Kecintaannya pada MU tak hilang meski ia sempat hijrah ke Everton. (us.bola.viva.co.id, crawled on $06 / 02 / 2014$ )

Table 5. The cooccurances of hijrah with sport related words taken from WebCorp Live, Birmingham City University, (retrieved 07/10/2019) 
30: uari 2016. Berikut ini 5 pemain bintang yang hijrah ke Liga Super China pada bursa trans
31: Juventus, Axel Witsel akhirnya lebih memilih hijrah ke China. Gelandang timnas Belgia itu
32: yang sekarang membela Watford Odion Ighalo hijrah ke Liga Super China pada penutupan bu
33: ndeks « " Home Bola Sepakbola Dunia Eriksen Hijrah ke Inter Milan, Alli: Kami Akan Meri
39: Depan Zlatan Ibrahimovic Zlatan Ibrahimovic Hijrah Ke Ac Milan?? Kondisi Fisik Ibrahimo
47: rkan hari Kembali Home bola Mario Mandzukic Hijrah ke Klub Qatar Reporter: Antara Editor
49: a Liga Spanyol Presiden La Liga Takut Messi Hijrah dari Barcelona Kompas. com - 11/10/:40
50: Namun ia akhirnya menurungkan niat untuk hijrah dari Spanyol dan sampai sekarang masi
53: Bola Liga Spanyol Marcelo Persilakan Neymar Hijrah ke Real Madrid Kompas.com - 20/07/201
54: gan tangan terbuka seandainya Neymar memilih hijrah ke klubnya. Kondisi Neymar di Paris
55: la Sports Valentino Rossi Akui Terbuka untuk Hijrah ke Petronas Yamaha SRT Liputan6. com04
58: kataan Tebas merujuk pada kasus Neymar yang hijrah dari Barcelona beberapa waktu lalu.
66:masa karir nya di PSG 1 musim lagi lalu akan hijrah ke real madrid setelah menghabiskan

Aside from the use of the word hijrah in the context of sport (Table 7 and 8), hijrah can also be found in the context of Indonesia celebrity's fashion. Some celebrities in Indonesia who decide to change their appearance to a more religious look or change their way of life to a more religious one are called doing hijrah. This phenomenon is used by the media as a commodity. That is why in the recent corpora, the word hijrah can be found in the context as the following concordance lines in Table 9.

Table 9. The cooccurances of hijrah with celebrity names taken from WebCorp Live, Birmingham City University, (retrieved 07/10/2019)

\begin{tabular}{|c|c|}
\hline 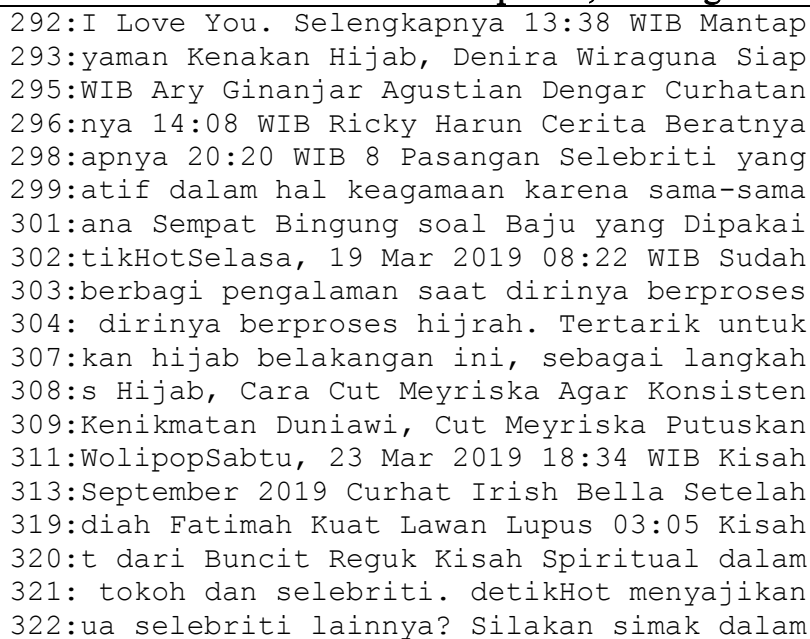 & 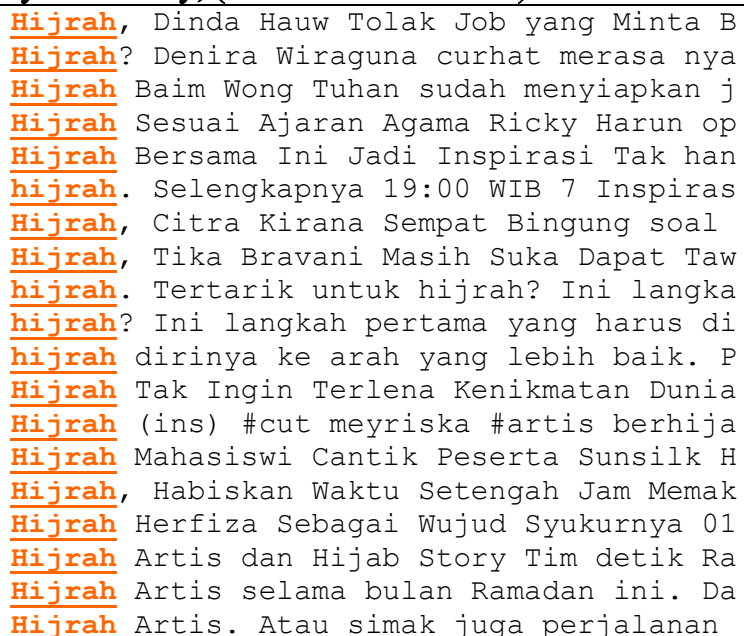 \\
\hline
\end{tabular}

The data from the corpus presented above shows that the meaning of the word jahanam and hijrah has changed from its original meaning. Their meanings have changed from time to time. The word jahanam is no longer used solely in religious contexts; its uses are now widespread. The word is used in any context that associates with evil or crime. Some people even use the word to name and describe food. The meaning of jahanam has expand to 'evil', 'strong as hell', and 'hot as hell'. The same thing applies to the word hijrah. This word is no longer used only in the field of Islam, but also has expanded into sports field, especially soccer. Hijrah in this soccer field means to change home club. The use of the word hijrah in this context only occurs in Indonesian.

Referring to the types of changes in meaning by Riemer (2010) and Geeraerts (2010), jahanam and hijrah experience an expansion of meaning. According to them, semantic change can be influenced by many factors, among of them are:

a) development in the field of science and knowledge,

b) development of word usage,

c) development of social culture,

d) exchange of sensory responses,

e) association of a word.

In the case of these two words, the change in meaning occurs because of the development of social culture. Indonesia is a country with a Muslim majority so that they understand several Arabic vocabularies related to religion. Because they understand the meaning, Indonesian speakers 
do not feel guilty when using the word in other contexts as long as the meaning is almost the same or does not stray too far (Alasmari et. al., 2017).

The data also shows that the difference in the use of the two words in context mostly occurred in the 20th century. In this century, Indonesian people have been flooded with information from abroad so that there are many changes in social and cultural order. This is what causes changes in meaning in several words, including the word jahanam and hijrah.

\section{Conclusion}

This study has shown how the word jahanam and hijrah that are used in Indonesian language differ both in use and meaning from their origin. This study has also shown that old manuscripts including Islamic text that compiled in a corpus are very useful to be used to analyse change in meaning of words using corpus linguistics method. The change in meaning can be seen from the context where the words are used as well as from the collocation. To analyse that phenomenon manually from one text to another will take months of time. By using digitised text in a corpus, it took only a couple of minutes to get the results.

Today, a specific Islamic corpus that contains only Islamic text has not yet been developed. Digitalization of Islamic texts could be a starting point to the compilation of such corpus. Considering that Islamic teaching based on the Quran is fixed and never change from time to time, Islamic corpus could become a reference corpus for analysing various phenomena in various subjects related to Islam.[]

\section{References}

Alasmari, Jawharah., J.C.E. Watson, \& D.E. Atwel. 2017. "Using the Quranic Arabic Corpus for Comparative Analysis Of The Arabic And English Verb Systems", International Journal on Islamic Applications in Computer Science And Technology, Vol. 5, No. 3.

Badan Pengembangan dan Pembinaan Bahasa. 2016. Kamus Besar Bahasa Indonesia edisi $V$. Jakarta: Kementerian Pendidikan dan Kebudayaan.

Berg, B. 2007. "Presence and Power of the Arab Idiom in Indonesian Islamic Musical Arts", Paper Presented at Conference on Music in the World of Islam, 8-13 August 2007 in Assilah.

Chung, Siaw-Fong. 2011. "Uses of ter- in Malay: A Corpus-based Study", Journal of Pragmatics, Vol. 43.

Fang, Liauw Yock. 1991. Sejarah Kesusastraan Melayu Klasik Jilid I. Jakarta: Penerbit Erlangga.

Gallop, Annabel Teh. 2013. "The Language of Malay Manuscript Art: A Tribute to Ian Proudfoot and the Malay Concordance Project", International Journal of the Malay World and Civilisation, Vol. 1, No. 3.

Geeraerts, Dirk. 2010. Theories of Lexical Semantics. Oxford: Oxford University Press.

Jalaludin, Nor Hashimah., Anida Sarudin, \& Zaharani Ahmad. 2012. "Peluasan Makna Alim: Analisis Semantik Kognitif”, GEMA Online Journal of Language Studies, Vol. 12, No. 2.

Jones, Russel., et.al. (eds). 2007. Loanwords in Indonesian and Malay. Leiden: KITLV.

Julul, Ali Ahmad., N.M. Rahmawati, D.A. Kwary, N.W. Sartini. 2019. "Semantic Adaptations of The Arabic Loanwords in The Indonesian Language“, Mozaik Humaniora, Vol. 19, No. 2.

Malay Concordance Project. 2019. Australian National University. Retrieved in early 2019 from http://www.mcp.anu.edu.au.

Mozaffari Falarti Maziar. 2012. Malay Kingship in Kedah: Religion, Trade, and Society. AsiaWorld. Rowman \& Littlefield (Lexington), Lanham. 
Arabi : Journal of Arabic Studies

O’Donnell, M. B. 2008. "Principles of Corpus Construction", Corpus Linguistics Summer Institute 2008, Unpublished Material, University of Liverpool.

Perrin, D., \& C. Kramsch (Ed.). 2019. Transdisciplinarity in Applied Linguistics. John Benjamins PublishingCompany. Accessed March 12, 2019 https://doi.org/10.1075/aila.00010.int

Proudfoot, I. 1991. "Concordances and Classical Malay", Bijdragen tot de Taal-, Land- en Volkenkunde, Vol. 147, No. 1.

Pusat Pembinaan dan Pengembangan Bahasa. 1996. Senarai Kata Serapan dalam Bahasa Indonesia. Jakarta: Departemen Pendidikan dan Kebudayaan.

Riddell, Peter. 2012. "From Kitab Malay to Literary Indonesian: A Case Study in Semantic Change", Studia Islamika Indonesian Journal for Islamic Studies, Vol. 19, No. 2.

Riemer, Nick. 2010. Introducing Semantics. Cambridge: Cambridge University Press.

Sinclair, J. 2004. Trust The Text: Language, Corpus, And Discourse. London: Routledge.

van Dam, N. 2010. “Arabic Loanwords in Indonesian Revisited”, Bijdragen tot de Taal-, Land- en Volkenkunde(BKI), Vol. 166, No. 2/3.

Wade, G., \& T. Li (Ed.). 2012. Anthony Reid and the Study of the Southeast Asian Past. Singapore: ISEAS-Yusof Ishak Institute.

WebCorp Live. 2019. Birmingham City University. from http://www.webcorp.org.uk/ live/search.jsp?search=jahanam

Wortschatz Corpora Collection. 2019. University Leipzig. from https://corpora.unileipzig.de/en?corpusId=ind_mixed_2013

Zahra, Tehseen., \& Akhtar Abbas. 2018. "Pedagogical Implications of Corpus-Based Approaches to ELT in Pakistan", Journal of Education and Educational Development, Vol. 5, No. 2. 